more powerfully on particles of ice than on drops of water. I venture to offer the following suggestions.

Let us co sider what happens when an ice cloud is forming. Dust particles, no doubt, act as nuclei to ice crystals as well as to water drops; so that a number of crystals will start into existence about the same time. Soon there will be no more dust particles of sufficient size to form nuclei. The rate of deposition on a crystal will be proportional to its surface, so all the crystals will grow in diameter at the same rate. The ratio of the largest diameter to the smallest will become less. In fact the crystals will become more uniform in size. No doubt, too, the supply of aqueous vapour near a large crystal will be con sumed more rapidly than it can be refunded by diffusion. So the larger crystals will grow somewhat more slowly. These are causes tending towards uniformity, They account for the observed fact that they are newly formed clouds, which show the brightest colours, though when they first come into view they are white. It is easy to give reasons why some clonds should lose their colour so soon. Varying conditions may affect the growth of different layers of particles in a different manner, or a slight increase in the rate of deposition may call new dust particles into action.

In the case of water clouds there are two special causes brou sht into action against uniformity. Sir Willian Thomson has shown that the maximum vapour-tension at the surface of water is largely increased when the surface is highly convex. So the large drops will grow more rapidly than the small ones, and the range of size will be more and more extended. Secondly, whenever two drops of water come into collision, they will combine into one larger one.

In conclusion I may remark that St. Moritz is 6 soo feet above sea-level, and the iridescent clouds were generally above the surrounding mountains, i.e. at least II, 500 feet above sea-level. On some days the sky was overspread at a great height, with a thin haze gathered here and there into denser streaks (cirrostratus?). The haze sometimes formed coronæ close around the sun. I have not made out more than two spectra. From rough measures of the diameters of the rings, I find for the diameters of these filaments values varying from $04 \mathrm{~mm}$. to $.07 \mathrm{~mm}$.

St. Moritz, Switzerland, March 14

\section{Aino Hairiness and the Urvolk of Japan}

IN Mr. B. H. Chamberiain's remarkable and instructive monograph on the Ainos, contained in the first number of the Memoirs of the Literature College of the Imperial University of Japan, just published, will be found an explanation of the different conclusions that have been arrived at by different observers as to the hairiness of that singular people, equally isolated, so far as our present knowledge extends, by language and by physical characteristics from all surrounding races. When I spent some days among these so-called savages in 1865 or 1866 , I had the opportunity of examining some four or five score of them, ch efly men, and in every individual I found the phenomenon of hairiness more or less marked. The sternal, inter-scapular, and gluteal regions were, in particular, thus provided with a natural covering, the very regions where such a protection from the drip of rain would be most serviceable. I remember well that in some individuals the gluteal fur was so abundantly developed that thick tufts of hair, several inches long, could be grasped in the hand. But recent travellers have been struck by the number of natives they met with deficient in hairiness-whether they were proportionately lacking in face-hair is not stated-and it has been doubted whether hairiness is really an Aino characteristic. Dr. Baelz's investigations have, however, amply vindicated the claim of the Ainos to be the hairiest people in the world, and now $\mathrm{Mr}$. Chamberlain shows that the smooth-bodied natives are in fact half-breeds, the progeny of native mothers by Japanese fathers. Unions of this kind have probably increased in frequency during the last two decades. Between the two races, however, some incompatibility seems to exist, for their progeny exhibit a diminished fertility. "The second generation," says Mr. Chamberlain, on the authority of the Rev. Mr. Batchelor, who has lived for years among the Ainos, and contributes an exhaustive grammar of their language to the volume of Memoirs before me, "is almost barren; and such children as are born-whether it be from two half-breed parents, or from one half-breed parent and a member of either pure race-are generally weakly. In the third or fourth generation the family dies out."
The injury to the reproductive system caused by this "miscegenation"-a phenomenon not unparalleled in the history of man, and proving the existence in man, as in other organisms, of a tendency to specific variation-has an important bearing upon the much-debated question of the proportion of Aino blood that runs in the veins of the Japanese of to-day. Mr. Chamberlain, chiefly from philological considerations based upon an examaination of place-names, arrives at the conclusion that the Urvolk of the Japanese group, from the extreme south to the furthest north, was an Aino race, and we know from history that up to the time of Yoritomo (twelfth century A.D.), and probably later, the northern balf of the main island was still, to some extent, peopled by Ainos. Yet even the northern Japanese are smooth. bodied, although it is extremely unlikely that "miscegenation" did not obtain between their Japanese ancestors and the aborigines. In the light of Mr. Batchelor's observations the explanation of this apparent anomaly is easy. The half-breeds died out, and the prepotency of the Japanese in numbers and civilisation gradually expelled the Aino element from the population, which has thus become an almost purely Japanese one.

It must not, nevertheless, be forgotten that at least two distinct races may still be traced in the existing population of the Japanese group. One is slim, high-headed, and often aquilinenosed; the other stouter and broader, more brachycephalic, and flat-nosed. Excellent types of both, especially of the first, will be found in Siebold's "Nippon Archiepf." The former constituted the military class of Old Japan, the latter the peasantry; and of the latter some degree of hairiness of the limbs is a not uncommon characteristic. The drawings of Hokusai sufficiently prove this assertion, which the experience of every resident in Japan will confirm. It may the efore be safely assumed that the elimination of the Aino element has not been complete. For my own part I believe that the earliest inhabitants of Japan were tribes of Malayo-Polynesian blood coming from the south, and of Aino blood coming from the north. Altaic immigrants followed, and, partly perhaps through some degree of reproductive prepotency, gave a characteristic and predominant stamp to the population without total elimination of its aboriginal elements.

University of London, March $2 \mathbf{I}$

F. V. DICKINS

\section{Units of Weight, Mass, and Force}

Having read with mucli interest Prof. Greenbill's letter in NATURE of March 24, p. 486, I am inclined to think that much of the perplexity felt by some who begin the study of dynamics arises from the want of names for the units of the various magnitudes with which the science deals. We have names for units of time, space, mass, force, work; but no names for units of velocity, acceleration, impulse, momentum, \&c. I venture to siggest the following :- Let the unit velocity be that with which a point describes uniformly one foot per second. Let this unit be called a vel. Let the unit acceleration be that whereby the velocity is uniformly changed by one vel per second. Let this unit be called a cel. Then everything becomes clear. E.g. the meaning of the equation $W=m g$ is seen to be this : The weight of a mass of $m$ pounds at a place where the acceleration arising from the mulual stress between it and the mass of the earth is $g$ cels being $W$ poundals, the numbers $W m g$ are connected by the equation $W=m g$. Then, for the sake of the beginner, let the names of the units be given thus: $W=m g$ poundals, $m=\frac{W}{g}$ pounds, $g=\frac{W}{m}$ cels. It is too common to see acceleration expressed in feet per second, instead of in vels per second. If the weight of a mass of $m$ pounds be defined to be the mutual stress between it and the mass $e$ pounds of the earth, it is evident that the weight of $e$ attracted by $m$ is the same as the weight of $m$ attracted by $e$; and, in the absence of either, the other would have no weight.

Bardsea, March 29

EDWARD GEOGHEGAN

\section{The Earthquake in the Riviera}

THOUGH there can be no question as to the amount of damage done by the late earthquake-I am writing in a shed, the hote being destroyed-I think that the violence of the shock has perhaps been very greatly exaggerated. I have only been abl to make a flying visit to this place and to Diano Marina, but I cannot help being struck by the fact that the peculiar archi tecture is the main cause of the large amount of destruction 